ARTICLE

\title{
Dynamic anoxic ferruginous conditions during the end-Permian mass extinction and recovery
}

M.O. Clarkson ${ }^{1}$, R.A. Wood ${ }^{1}$, S.W. Poulton ${ }^{2}$, S. Richoz ${ }^{3}$, R.J. Newton ${ }^{2}$, S.A. Kasemann ${ }^{4}$, F. Bowyer ${ }^{1}$ \& L. Krystyn ${ }^{5}$

The end-Permian mass extinction, $\sim 252$ million years ago, is notable for a complex recovery period of $\sim 5$ Myr. Widespread euxinic (anoxic and sulfidic) oceanic conditions have been proposed as both extinction mechanism and explanation for the protracted recovery period, yet the vertical distribution of anoxia in the water column and its temporal dynamics through this time period are poorly constrained. Here we utilize Fe-S-C systematics integrated with palaeontological observations to reconstruct a complete ocean redox history for the Late Permian to Early Triassic, using multiple sections across a shelf-to-basin transect on the Arabian Margin (Neo-Tethyan Ocean). In contrast to elsewhere, we show that anoxic non-sulfidic (ferruginous), rather than euxinic, conditions were prevalent in the Neo-Tethys. The Arabian Margin record demonstrates the repeated expansion of ferruginous conditions with the distal slope being the focus of anoxia at these times, as well as short-lived episodes of oxia that supported diverse biota.

\footnotetext{
${ }^{1}$ School of GeoSciences, University of Edinburgh, James Hutton Road, Edinburgh EH9 3FE, UK. ${ }^{2}$ School of Earth and Environment, University of Leeds, Leeds LS2 9JT, UK. ${ }^{3}$ Institute of Earth Sciences, NAWI Graz, University of Graz, Heinrichstraße 26, 8010 Graz, Austria. ${ }^{4}$ Department of Geosciences and MARUM-Center for Marine Environmental Sciences, University of Bremen, 28334 Bremen, Germany. ${ }^{5}$ Institute for Palaeontology, Vienna University,

Althanstrasse 14, 1090 Vienna, Austria. Correspondence and requests for materials should be addressed to M.O.C. (email: matthew.clarkson@otago.ac.nz).
} 
hanerozoic oceanic anoxic events (OAEs) represent extreme periods of Earth history that record major disturbances to the carbon cycle ${ }^{1}$. OAEs typify greenhouse climate states and have played a major role in dictating evolution and extinction events ${ }^{1}$. In particular, euxinic (anoxic and sulfidic) water column conditions have been implicated as a major driver for the endPermian mass extinction ${ }^{2-6}$, which represents the greatest mass extinction of the Phanerozoic with a uniquely protracted and complex $\sim 5 \mathrm{Myr}$ recovery period ${ }^{7}$. Once described as a 'superanoxic' event that lasted for $\sim 20 \mathrm{Myr}$ (ref. 8), our understanding of the Permian Triassic interval has since been refined by evidence for changes in the spatial and temporal distribution, and intensity, of anoxia ${ }^{9-11}$. These studies highlight recurrent anoxia that has an unresolved and complex relationship to both evolutionary dynamics and the global carbon cycle.

Refined techniques for identifying the precise nature of ocean redox conditions ${ }^{12}$ have increasingly highlighted the prevalence of anoxic non-sulfidic (ferruginous conditions) through Earth history $^{13}$, including during Phanerozoic periods of anoxia ${ }^{14,15}$. However, despite suggestions of the extreme redox state of euxinia $^{4,6}$, no redox studies have yet employed methods capable of distinguishing anoxic ferruginous conditions from euxinic conditions across the full Permo-Triassic extinction and recovery interval. This is critical as the precise nature of water column chemistry during periods of anoxia has profound implications for the evolution of the biosphere and for feedbacks associated with the biogeochemical cycling of elements such as nitrogen ${ }^{16}$ and phosphorus $^{14}$ in the sediment and water column. In addition, no study has yet applied redox proxies of any kind to produce a vertically resolved record of the entire water column, even though this is crucial for understanding anoxic events ${ }^{17,18}$. Without such records, a detailed causal understanding of the relationship between anoxia, euxinia, extinction events and wider carbon cycle processes is not possible.

To address this, we have undertaken Fe-speciation, Fe/Al and pyrite $S$-isotope $\left(\delta^{34} S_{\text {pyrite }}\right)$ analyses of a suite of sediments covering a shelf to basin depth transect across the Arabian Margin (Fig. 1), in the central Neo-Tethyan Ocean Our sites include shelf carbonates ${ }^{19-21}$, continental slope sediments (Sumeini Group $^{22,23}$ ), basinal deposits (Hawasina Basin ${ }^{24}$ ) and offshore highs (Ba'id $\left.{ }^{25,26}\right)$. Detailed section descriptions are given in Supplementary Note 1. Our samples primarily span from the Late Permian ( $\sim 260 \mathrm{Ma})$, across the extinction interval (EI) and the Permian Triassic Boundary (PTB), to the Late Spathian. This unique depth transect allows for a particularly well-resolved vertical and temporal record of regional redox dynamics within an established carbon isotope and biostratigraphic framework ${ }^{20,23,24,27}$.We identify a temporally and spatially dynamic redox system that shows expansions of anoxic ferruginous conditions across the Arabian Margin. Expansions occur at the EI, the Dienerian/Smithian boundary and during the Smithian/Spathian boundary, with the distal slope, rather than the deep basin, being the focus of anoxia at these times. Our data also demonstrate short-lived interludes of oxic water column conditions, which in contrast to ferruginous episodes are characterized by a diverse fossil record, suggesting that biotic recovery in the Neo-Tethys was rapid during these oxygenation episodes.

\section{Results}

Fe systematics. Fe-speciation is a widely utilized proxy for regional water column redox conditions ${ }^{12,18}$, being able to differentiate oxic from anoxic ferruginous and euxinic conditions. This sequential chemical extraction technique gives a measure of highly reactive $\mathrm{Fe}$ to total $\mathrm{Fe}\left(\mathrm{Fe}_{\mathrm{HR}} / \mathrm{Fe}_{\mathrm{T}}\right)$. $\mathrm{Fe}_{\mathrm{HR}}$ refers to Fe minerals that are considered highly reactive towards biological and abiological reduction under anoxic conditions, and includes carbonate-associated $\mathrm{Fe}\left(\mathrm{Fe}_{\text {carb }}\right.$; for example, ankerite and siderite), ferric (oxyhydr)oxides ( $\mathrm{Fe}_{\mathrm{ox}}$; for example, goethite and haematite), magnetite $\mathrm{Fe}\left(\mathrm{Fe}_{\mathrm{mag}}\right)$ and $\mathrm{Fe}$ sulfide minerals $\left(\mathrm{Fe}_{\mathrm{py}}\right.$; for example, makinawite and pyrite).
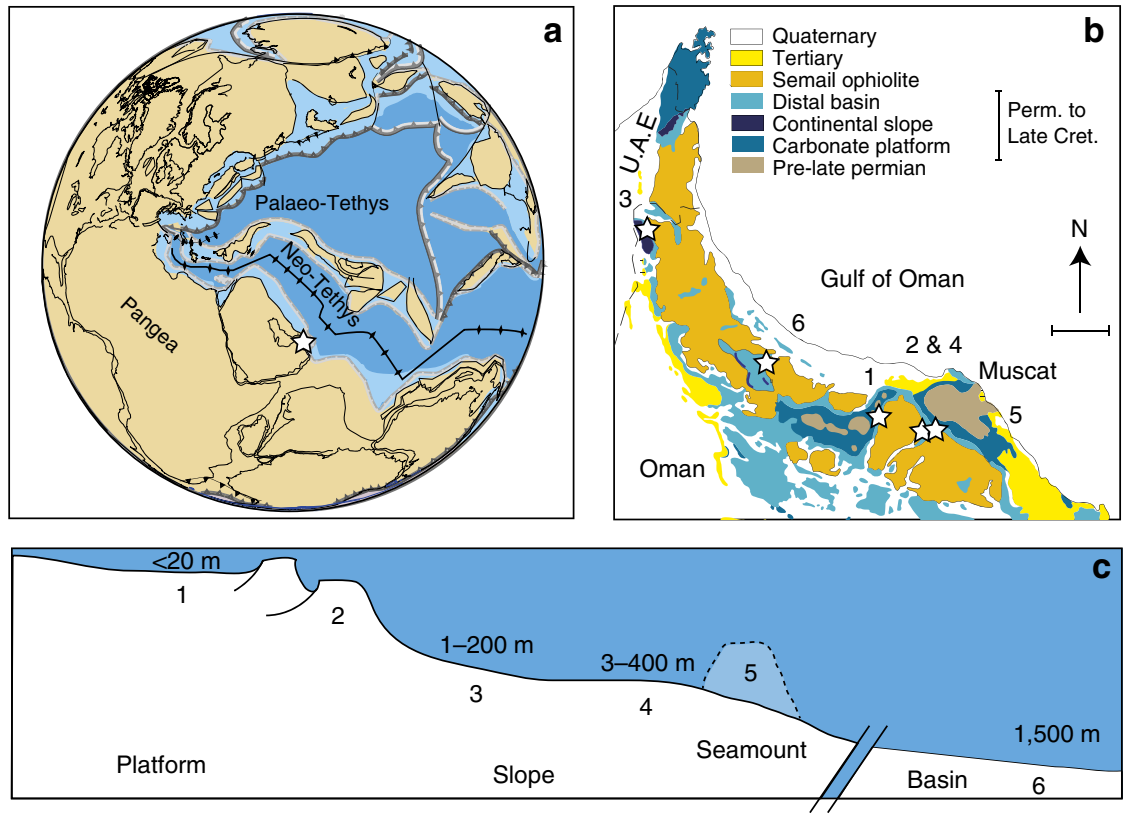

Figure 1 | Geological information. (a) Late Permian palaeogeographic reconstruction ${ }^{53,70}$ with the location of the Arabian Margin marked. (b) Simplified geological map of Oman and UAE ${ }^{70}$ showing site localities; scale bar, 50 km; (1) Saiq Plateau; platform, (2) Wasit Block; distal platform; (3) Sumeini; middle slope, (4) Wadi Wasit South and Radio Tower; distal slope, (5) Ba'id; seamount, (6) Buday'ah; deep basin. (c) Schematic basin cross-section for the Dienerian (not to scale) showing estimated palaeo-depths (based on facies) and site numbers as in $\mathbf{b}$. See Supplementary Note 1 for detailed site descriptions. 


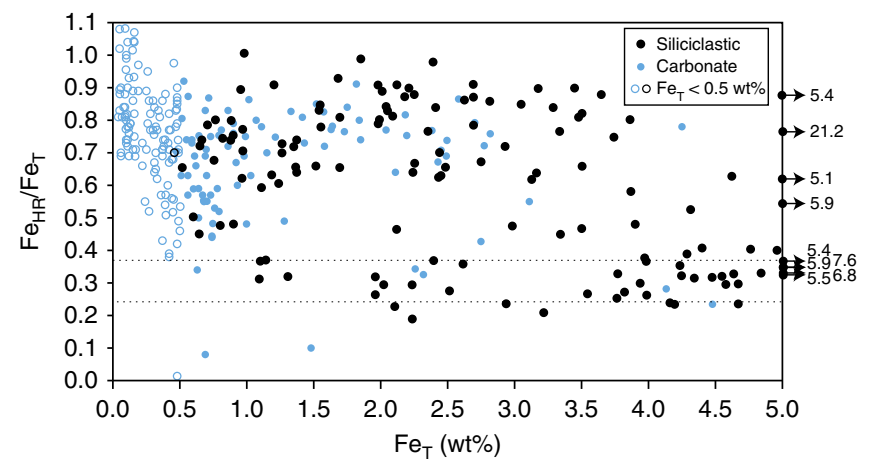

Figure 2 | Distribution of Fe-speciation data as a function of total Fe. Samples are coloured by lithology (black $=$ siliciclastic, blue $=$ carbonate). Dashed lines are at 0.22 and 0.38 , marking the interpretive thresholds for $\mathrm{Fe}$-speciation. Carbonate samples with $\mathrm{Fe}_{\mathrm{T}}<0.5 \mathrm{wt} \%$. (open blue circles) have $\mathrm{Fe}_{\mathrm{HR}} / \mathrm{Fe}_{\mathrm{T}}$ ratios almost exclusively $>0.38$, suggesting spurious enrichments of $\mathrm{Fe}_{\mathrm{HR}}$ similar to modern sediments ${ }^{35}$. $\mathrm{Fe}_{\mathrm{T}}$ and $\mathrm{Fe}$-speciation data for these samples cannot be interpreted. $\mathrm{As}_{\mathrm{Fe}} \mathrm{Fe}_{\mathrm{T}}$ decreases there may also be a decrease in precision, leading to excessively high $\mathrm{Fe}_{\mathrm{HR}} / \mathrm{Fe}_{\mathrm{T}}$ values $>1$. Extreme values have therefore been removed from the data set.

$\mathrm{Fe}_{\mathrm{HR}} / \mathrm{Fe}_{\mathrm{T}}$ ratios of $<0.22$ provide robust evidence for deposition from an oxic water column ${ }^{13,28}$. Anoxic water column conditions are identified when $\mathrm{Fe}_{\mathrm{HR}} / \mathrm{Fe}_{\mathrm{T}}$ ratios are $>0.38$, which result from the additional water column formation of either $\mathrm{Fe}$ sulfides under euxinic conditions, or non-sulfidized $\mathrm{Fe}$ minerals under ferruginous conditions ${ }^{29,30}$. $\mathrm{Fe}_{\mathrm{Py}} / \mathrm{Fe}_{\mathrm{HR}}$ ratios can then distinguish ferruginous $(<0.7-0.8)$ from euxinic $(>0.7-0.8)$ conditions ${ }^{13,28,31,32}$. Values of $\mathrm{Fe}_{\mathrm{HR}} / \mathrm{Fe}_{\mathrm{T}}$ between 0.22 and 0.38 are somewhat equivocal, and may represent either oxic or anoxic deposition ${ }^{28,33,34}$. In the latter case, diagenetic transfer of $\mathrm{Fe}_{\mathrm{HR}}$ minerals to Fe-rich clay minerals, or rapid sedimentation, can diminish $\mathrm{Fe}_{\mathrm{HR}}$ enrichments. During diagenetic transformation of $\mathrm{Fe}_{\mathrm{HR}}$ to unreactive $\mathrm{Fe}$ minerals $\left(\mathrm{Fe}_{\mathrm{UR}}\right)$, the total $\mathrm{Fe}$ enrichment is still preserved and hence we also utilize $\mathrm{Fe} / \mathrm{Al}$ ratios to provide further information on water column redox conditions ${ }^{18,33}$, where oxic marine sediments have average ratios of $0.55 \pm 0.11$ (refs 34,35). Dilution of $\mathrm{Fe}_{\mathrm{HR}}$ by rapid sedimentation does not appear to have affected our samples (Supplementary Note 2). Oxidative weathering of samples could potentially mask $\mathrm{Fe}_{\mathrm{py}}$ enrichments but would not alter $\mathrm{Fe} / \mathrm{Al}$ ratios. The high proportion of $\mathrm{Fe}_{\text {carb }}$ in our samples, however, argues against this process significantly affecting our results (Supplementary Note 3).

$\mathrm{Fe}$-speciation has traditionally been applied to fine-grained siliciclastic rocks, and $60 \%$ of the samples we utilize here for Fe-speciation are siliciclastics. In addition, a recent assessment has demonstrated the robust nature of the proxy in carbonaterich sediments, providing $\mathrm{Fe}_{\mathrm{T}}$ is $>0.5 \mathrm{wt} \%$ (ref. 35). When $\mathrm{Fe}_{\mathrm{T}}$ is $<0.5 \mathrm{wt} \%$, carbonate samples have greater potential to be spuriously enriched in $\mathrm{Fe}_{\mathrm{HR}}$ from processes other than the water column enrichments that arise under anoxic conditions. This potential effect is apparent in our samples from the distribution of $\mathrm{Fe}_{\mathrm{HR}} / \mathrm{Fe}_{\mathrm{T}}$ against $\mathrm{Fe}_{\mathrm{T}}$ where samples with $\mathrm{Fe}_{\mathrm{T}}$ $<0.5$ wt $\%$ almost exclusively give $\mathrm{Fe}_{\mathrm{HR}} / \mathrm{Fe}_{\mathrm{T}}$ ratios $>0.38$ (Fig. 2), despite independent evidence of oxygenation from bioturbation and benthic fauna associated with some samples (Supplementary Figs 1-7). Hence, in the present study, we do not utilize Fe-speciation or Fe/Al data for samples with $<0.5 \mathrm{wt} \% \mathrm{Fe}_{\mathrm{T}}$. Instead, for these samples, we rely on palaeontological information to identify whether oxic water column conditions were likely prevalent. In support of our approach, interbedded carbonates and siliciclastics give consistent redox interpretations in all cases (Figs 2 and 3; Supplementary Figs 1-7).

The two indicators of anoxia generally show consistent results (Fig. 3; Supplementary Figs 1-7; Supplementary Tables 1-7); however, across some intervals, $\mathrm{Fe} / \mathrm{Al}$ ratios are relatively low, which contrasts with clear $\mathrm{Fe}_{\mathrm{HR}} / \mathrm{Fe}_{\mathrm{T}}$ enrichments (starred intervals, Fig. 3). For example, this pattern is seen in the Late Permian and mid-Dienerian of the deep basin, around the anoxic episode at the EI in the mid-slope, at the end-Dienerian in the platform marls and shales, and in both slope sites from the mid-to-late Smithian in laminated carbonates. These data are unlikely to reflect an addition of $\mathrm{Fe}_{\mathrm{HR}}$ during deep burial dolomitization, as such samples were avoided in this study (Supplementary Note 4). It is also unlikely that these limited samples reflect deposition under suboxic conditions or $\mathrm{Fe}_{\mathrm{HR}}$ dilution due to high sedimentation rates, as this would affect both $\mathrm{Fe} / \mathrm{Al}$ and $\mathrm{Fe}_{\mathrm{HR}} / \mathrm{Fe}_{\mathrm{T}}$ ratios in the same manner. However, $\mathrm{Fe} / \mathrm{Al}$ tends to suffer from greater inherent variability due to local compositional variability in the source rocks, and therefore using a local oxic baseline is recommended where possible ${ }^{18,33}$. A major transgression during the mid-to-late Permian created extensive carbonate deposition landward of our sites ${ }^{20}$. Erosion during the Early Triassic then penetrated down to the mid-Permian deposits only ${ }^{20}$. Thus, the hinterland lithogenic source of $\mathrm{Fe}$ for the Arabian Margin was primarily limited to low $\mathrm{Fe}$ carbonate sediments. Samples with elevated $\mathrm{Fe}_{\mathrm{HR}} / \mathrm{Fe}_{\mathrm{T}}$ and relatively low (or borderline) $\mathrm{Fe} / \mathrm{Al}$ ratios may then indeed reflect anoxic conditions, but $\mathrm{Fe}$ enrichments were either not sufficient to significantly increase $\mathrm{Fe} / \mathrm{Al}$ ratios above the natural variability, or the regional oxic $\mathrm{Fe} / \mathrm{Al}$ baseline was lower than the global average.

Water column redox conditions. Anoxic water column deposition is identified by elevated $\mathrm{Fe}_{\mathrm{HR}} / \mathrm{Fe}_{\mathrm{T}}$ and $\mathrm{Fe} / \mathrm{Al}$ ratios at three main time intervals across the Arabian Margin transect: the Changsingian and overlying EI, and the Dienerian-Smithian and Smithian-Spathian boundary intervals. There is strong evidence for more persistent anoxia, from consistently elevated $\mathrm{Fe}_{\mathrm{HR}} / \mathrm{Fe}_{\mathrm{T}}$ and $\mathrm{Fe} / \mathrm{Al}$ ratios, in the distal slope setting for much of the Early Triassic, while significant spatial and temporal variability is seen elsewhere in the basin. In addition, low $\mathrm{Fe}_{\mathrm{py}} / \mathrm{Fe}_{\mathrm{HR}}$ ratios throughout the succession (Fig. 3) demonstrate that anoxic intervals were ferruginous, with no evidence for the pyrite enrichments that would be prevalent under euxinic conditions.

In the Late Permian, high $\mathrm{Fe}_{\mathrm{HR}} / \mathrm{Fe}_{\mathrm{T}}$ and low $\mathrm{Fe}_{\mathrm{Py}} / \mathrm{Fe}_{\mathrm{HR}}$ ratios are first recorded in deep basin shales during the Late Capitanian to Early Changsingian (site 6, Fig. 3; Supplementary Fig. 7) and persisted until the end of the EI. The lowest samples here are radiolarian shales, a lithology that has not been tested rigorously for Fe-based redox proxies and thus the possibility of anoxia in the Capitanian to Wuchiapingian cannot be confirmed. Anoxic conditions appear only intermittently in mid-slope settings in the latest Changhsingian (C. changxingensis zone), where $\mathrm{Fe}_{\mathrm{HR}}$-enriched shales alternate with bioturbated limestones. Anoxia was then persistent throughout the EI until at least the I. isarcica zone (site 3, Fig. 3, Supplementary Fig 2 and 3), although the onset of extinction is not preserved due to a minor unconformity.

In the Griesbachian (within the I. isarcica zone), Fe-speciation and $\mathrm{Fe} / \mathrm{Al}$ data suggest that oxygenated conditions were present in the deepest basin (Fig. 3). At this time, the middle slope sediments show intense bioturbation (75-80 m, Supplementary Fig. 3), while other Arabian platform areas (site 2) display a highly diverse assemblage of crinoids, gastropods and bivalves that are not seen outside of the Neo-Tethys until the Spathian ${ }^{36}$. 


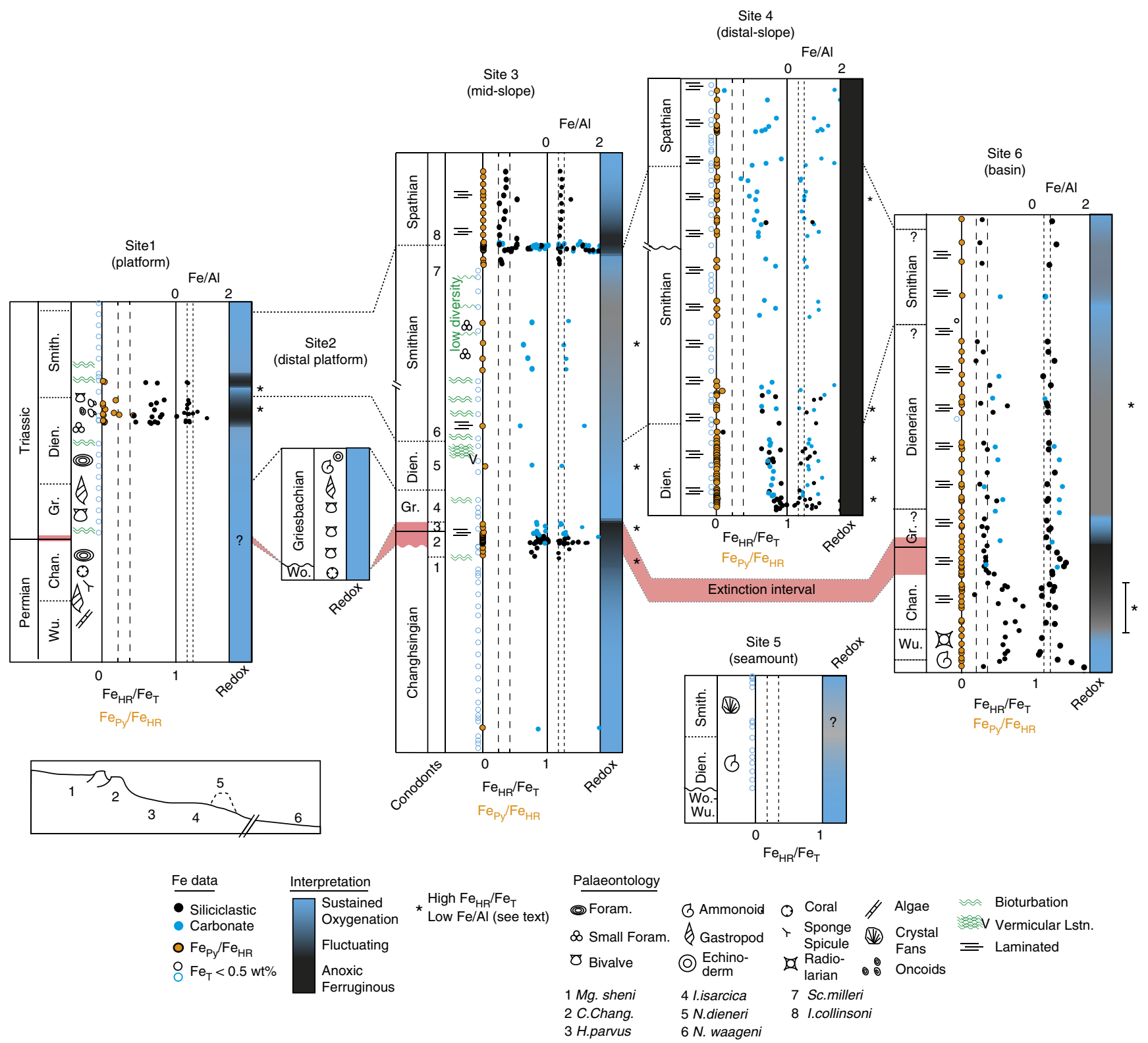

Figure 3 | Summary of Fe-speciation and Fe/Al records for the Arabian Margin. Samples where $\mathrm{Fe}_{T}>0.5$ wt $\%$ (closed circles) can be used confidently for Fe-speciation regardless of lithology ${ }^{35}$. Samples with $\mathrm{Fe}_{\mathrm{T}}<0.5 \mathrm{wt} \%$ (open circles) cannot be interpreted for $\mathrm{Fe}_{\mathrm{HR}} / \mathrm{Fe}_{\mathrm{T}}$ ratios as they may show spurious results ${ }^{35}$ (see text), but we nevertheless show the points at which these samples were taken. Data point colour identifies lithology for both Fe $\mathrm{T}_{\mathrm{T}}$ categories. Palaeontological information 27,36 is summarized and is particularly useful for identifying oxygenated conditions when $\mathrm{Fe}_{\mathrm{T}}<0.5$ wt\%. Fe/Al is used to help interpret $\mathrm{Fe}_{\mathrm{HR}} / \mathrm{Fe}_{\mathrm{T}}$ values between 0.22 and 0.38 (see text for discussion). Fe/Al scale is maximized at 2, values $>2$ can be seen in Supplementary Figs 1-7. Lines are shown at 0.22 and 0.38 for $\mathrm{Fe}_{\mathrm{HR}} / \mathrm{Fe}_{\mathrm{T}}$ ratios, 0.44 and $0.66(0.55 \pm 0.11)$ for $\mathrm{Fe} / \mathrm{Al}$. Sections are scaled for clarity with section breaks indicated corresponding to Supplementary Figs 1-7. Fe-speciation was not undertaken for site 2. Extinction interval shown in red. Not all conodont zones, as defined in South China, are identifiable in the Central Tethys, but key conodont occurrences are shown for the expanded site 3. Question marks refer to either uncertainties of redox interpretation or age correlations. Chan., Changsingian; Dien., Dienerian; Gr., Griesbachian; Smith., Smithian; Wo., Wordian; Wu., Wuchiapingian.

Together, this suggests a period of stable water column oxygenation for the entire region, when the Arabian Margin appears to have acted as a site for rapid biotic recovery ${ }^{36}$.

Records from the distal slope setting (site 4) begin in the Dienerian and suggest largely persistent anoxic ferruginous conditions (Fig. 3), with high $\mathrm{Fe}_{\mathrm{HR}} / \mathrm{Fe}_{\mathrm{T}}$ ratios and no evidence of bioturbation throughout the Early Triassic. During the Dienerian, the mid-slope sediments record a single $\mathrm{Fe}_{\mathrm{HR}}$ enrichment in laminated sediments followed by a restricted interval of vermicular limestones that ended around the Dienerian/Smithian boundary. The limited degree of bioturbation preserved by vermicular limestones indicates an unstable and rapidly fluctuating environment ${ }^{37}$. Together, these data suggest an environment that was predominantly anoxic on the distal slope, from at least the Dienerian, but which fluctuated between anoxic and oxic elsewhere (Fig. 3). The low $\mathrm{Fe}_{\mathrm{T}}$ sediments of the platform show bioturbation until the end-Dienerian, suggesting this setting remained oxygenated. This oxygenated period ended with an increase in $\mathrm{Fe}_{\mathrm{HR}} / \mathrm{Fe}_{\mathrm{T}}$, with low $\mathrm{Fe}_{\mathrm{Py}} / \mathrm{Fe}_{\mathrm{HR}}$, indicating a distinct period of ferruginous conditions in shallow waters; the only occurrence of this in the Arabian Margin record. Unfortunately, the mid-slope section contains minor 
unconformities and the lower sample resolution limits correlation of this anoxic pulse across the margin.

During the Smithian, the slope records show subtle variability in redox conditions. For the mid-slope in the early to mid Smithian there is a single $\mathrm{Fe}_{\mathrm{HR}}$-enriched laminated carbonate (Fig. 3; Supplementary Figs 2 and 3) followed by low $\mathrm{Fe}_{\mathrm{T}}$ samples with rare bioturbation. Corresponding distal-slope sediments also have low $\mathrm{Fe}_{\mathrm{T}}$ (56-78 m; Supplementary Fig. 4), precluding $\mathrm{Fe}$ proxy evaluation ${ }^{35}$, but nevertheless bioturbation is absent. A number of ferruginous samples (without bioturbation) are then present in the mid-slope during the mid-Smithian, followed again by low $\mathrm{Fe}_{\mathrm{T}}$ samples into the late Smithian $(0-210 \mathrm{~m}$; Supplementary Fig. 3). These low $\mathrm{Fe}_{\mathrm{T}}$ samples correspond to an increased bioturbation frequency and presence of small foraminifera. Interestingly, however, ichnodiversity remained low and was restricted to shallow tiers within the sediment ${ }^{23}$ (Fig. 3), suggesting only temporary periods of oxygenation. Oxic deposition is then recorded briefly by low $\mathrm{Fe}_{\mathrm{HR}} / \mathrm{Fe}_{\mathrm{T}}$ and $\mathrm{Fe} / \mathrm{Al}$ ratios in shales of the latest-Smithian (220-230 m; Supplementary Fig. 3). Integrating $\mathrm{Fe}$-speciation data with palaeontological observations across these two sites suggest rapidly fluctuating oxygenation of the mid-slope. This ceased abruptly near the Smithian/Spathian boundary, where both $\mathrm{Fe}$-speciation and $\mathrm{Fe} / \mathrm{Al}$ show clear enrichments, recording a return to anoxic conditions in the mid-slope, while anoxia continued in the distal slope. Conversely, platform records show low $\mathrm{Fe}_{\mathrm{T}}$ values at the Smithian/Spathian boundary (Fig. 3; Supplementary Fig. 1), and breccia deposits in the mid-slope contain disarticulated crinoid ossicles, together suggesting that oxygenated conditions were present, at least locally, in shallower waters. This brief anoxic episode was followed by a return of oxygenation in the mid-slope during the Spathian, with $\mathrm{Fe}_{\mathrm{HR}} / \mathrm{Fe}_{\mathrm{T}}$ and $\mathrm{Fe} / \mathrm{Al}$ returning to lower values.

The deep basin is more difficult to interpret as age uncertainties make correlation of these events problematic, but the record suggests fluctuating conditions throughout the Dienerian to Smithian, similar to the mid-slope site. The seamount section (site 5; Fig. 3) gives unique insight into the evolution of water column anoxia by capturing the mid-depth water column signature. The unusual carbonate fabrics preserved here during the Smithian (abiotic calcite spar, for example, Frutexites and Stromatactis) are indicators of atypical ocean chemistry during the Early Triassic ${ }^{25}$. It has been suggested that the presence of these fabrics at this isolated locality may be linked to its position within a fluctuating chemocline and resulting variability in calcium carbonate saturation state ${ }^{25}$. Low $\mathrm{Fe}_{\mathrm{T}}$ contents of these carbonate samples (Fig. 3; Supplementary Fig. 6) prevent interpretation of Fe-speciation data and thus the direct presence of water column anoxia cannot be confirmed. However, the close proximity of the seamount to a fluctuating chemocline is consistent with dynamic anoxia recorded in the adjacent slope environment.

Sulfur isotopes. Our $\delta^{34} S_{\text {pyrite }}$ data range from $-27.3 \%$ to $+32.5 \%$ for anoxic samples (Fig. 4), with the data skewed towards heavier values. Under euxinic conditions, a narrow range in $\delta^{34} S_{\mathrm{py}}$ is often found in modern and ancient environments ${ }^{38}$, due to sulfide production in a well-mixed water column. In contrast, diagenetic pyrite formation generally exhibits a wider range in $\delta^{34} S_{\text {py }}$ consistent with the magnitude of fractionations commonly found through bacterial sulfate reduction during early diagenesis $^{39}$. In comparison, isotopic records of Early Triassic seawater sulfate (from carbonate-associated sulfur; CAS) are highly positive (Fig. 4 ), ranging between -0.7 and $+44.1 \%$ (refs 40,41 ). The considerable overlap between the seawater sulfate and

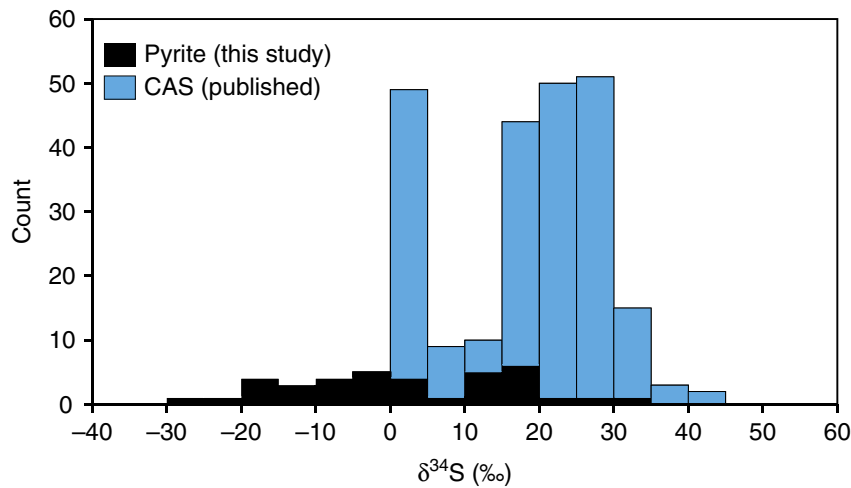

Figure 4 | S-isotope systematics. Comparison of new $\delta^{34} S_{p y}$ data with published values of $\delta^{34} S_{\text {seawater }}$ from Late Permian and Early Triassic CAS records 40,41 . The overlap between the two $\delta^{34} S$ records supports the inference of ferruginous conditions from Fe-speciation and suggests low background sulfate concentrations.

pyrite sulfur isotopic records is consistent with a relatively low seawater sulfate reservoir ${ }^{38,42}$

\section{Discussion}

Previous studies have identified both deeper water (using framboid size distributions) and photic zone (using biomarkers) euxinia periodically through the Late Permian and Early Triassic $4,6,43$. Euxinia appears particularly prevalent in the Palaeo-Tethys and the Panthallassic Oceans, with no conclusive reports for the Central Neo-Tethys. By contrast, all anoxic data presented here record low $\mathrm{Fe}_{\mathrm{Py}} / \mathrm{Fe}_{\mathrm{HR}}$ ratios, suggesting a predominantly ferruginous rather than euxinic water column. Fe-shuttling within a suboxic oxygen minimum zone (OMZ) could potentially create similar local enrichments in Fe-oxides ${ }^{44}$, resulting in high $\mathrm{Fe}_{\mathrm{HR}} / \mathrm{Fe}_{\mathrm{T}}, \mathrm{Fe} / \mathrm{Al}$ and low $\mathrm{Fe}_{\mathrm{Py}} / \mathrm{Fe}_{\mathrm{HR}}$ ratios. In this scenario, the reductive mobilization of $\mathrm{Fe}$ (II) under suboxic conditions may lead to depletion of $\mathrm{Fe}$ in the sediment underlying the OMZ itself ${ }^{44}$ (that is, Fe/Al below the lithogenic baseline combined with low $\mathrm{Fe}_{\mathrm{HR}} / \mathrm{Fe}_{\mathrm{T}}$ ratios). The mobilized $\mathrm{Fe}$ would then be transported within the suboxic OMZ and sequestered at the lower oxycline, leading to an $\mathrm{Fe}_{\mathrm{ox}}$ enrichment in bioturbated sediments below the $\mathrm{OMZ}^{44}$. This is not seen in our Permo-Triassic Arabian Margin record where the greatest enrichments of $\mathrm{Fe}_{\mathrm{HR}} / \mathrm{Fe}_{\mathrm{T}}$ are in the distal slope environment, where bioturbation is completely absent. Also, if the distal slope site were suboxic, we would expect depletions of $\mathrm{Fe}_{\mathrm{HR}}$, not enrichments, as these sediments would act as an $\mathrm{Fe}(\mathrm{II})$ source. Our data are therefore more consistent with distal slope anoxic ferruginous conditions, which expanded and contracted through time, leading to occasional $\mathrm{Fe}$ enrichments in shallower and deeper settings.

Our Fe-speciation data suggest an environment characterized by low pyrite burial, and sulfur isotopes, both from the $\delta^{34} S_{\mathrm{py}}$ presented here and previously published $\delta^{34} S_{\mathrm{CAS}}$ data ${ }^{40,41,45}$, are consistent with low sulfate concentrations in the water column during the PTB and the Early Triassic. The increase in bedrock weathering intensity in the Early Triassic ${ }^{46,47}$ would have liberated some sulfate from the continent, implying that the low-sulfate ocean state was a result of high sulfate removal, potentially through substantial pyrite deposition under euxinic conditions that are seen elsewhere ${ }^{4,45}$, augmented via the large-scale deposition of marine evaporites containing disproportionately large amounts of sulfate in the late Permian and earliest Triassic ${ }^{48}$. In addition to low ocean sulfate concentrations, the proximity of the Arabian Margin to the 

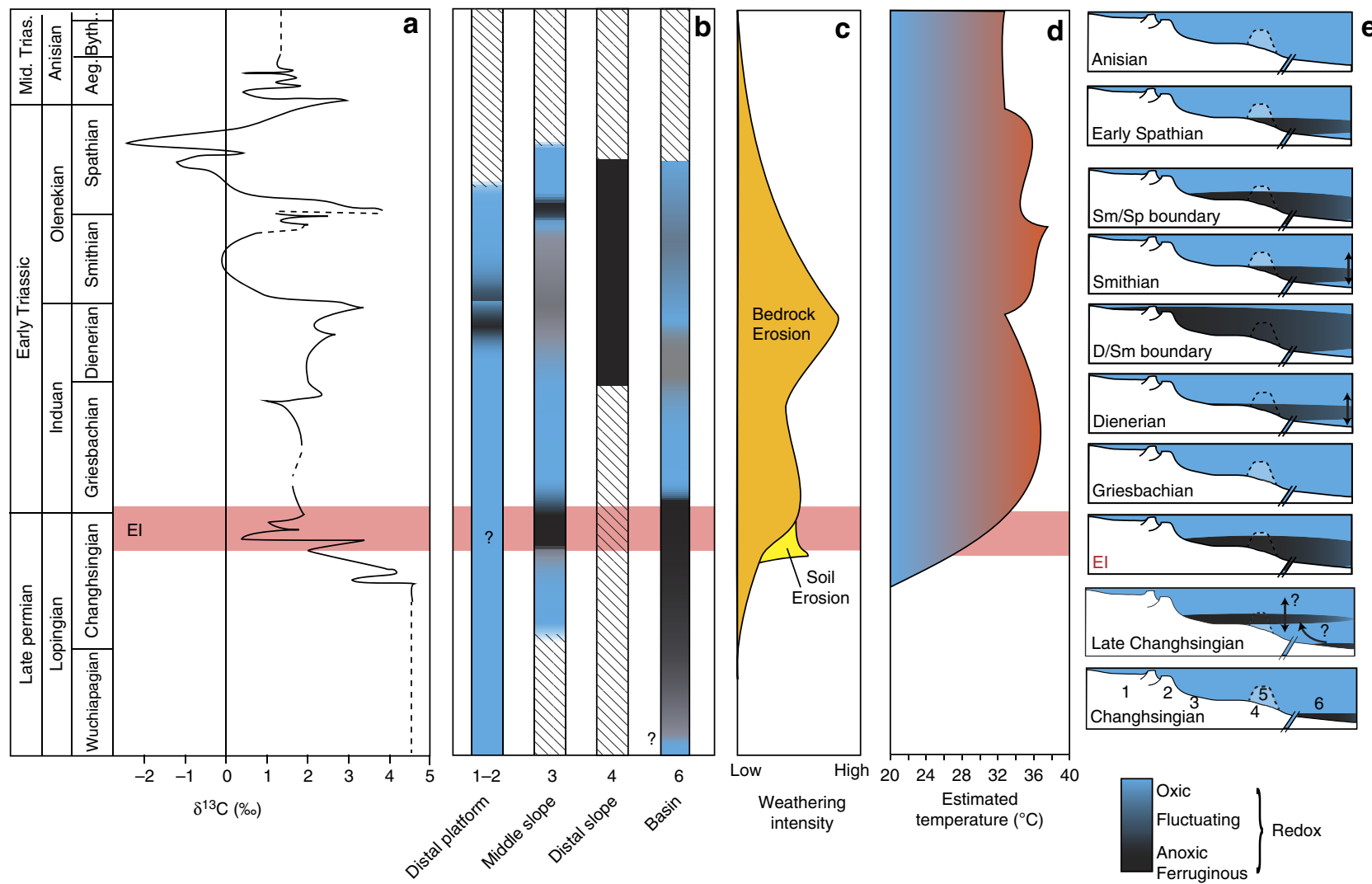

Figure 5 | Compilation of global records compared to the Arabian Margin redox record. (a) Regional $\delta^{13} \mathrm{C}$ curve from the Musandam Mountains, UAE that correlates well with global records and especially the sections presented here ${ }^{21}$. (b) Summary of redox interpretations from Fig. 2. Hashed areas are not preserved in the Arabian Margin. (c) Global weathering rates ${ }^{46}$ demonstrating an increase in soil erosion and silicate weathering, approximately coincident with the development of slope anoxia. (d) Equatorial temperature changes ${ }^{49}$. (e) Schematic diagram illustrating the redox dynamics of the Arabian Margin for the end-Permian and Early Triassic based on the data presented here. Arrows represent upwelling and expansions of an anoxic ferruginous wedge. Extinction interval (EI) shown as red horizontal box.

open ocean, and a limited flux of organic carbon, may have prevented conditions becoming sufficiently reducing for sulfide to accumulate in the water column, which is consistent with the absence of organic-rich black shales in the Arabian sites (Supplementary Figs 1-7).

The precarious balance between ferruginous and euxinic chemical states is dictated by the relative oceanic input fluxes of $\mathrm{Fe}_{\mathrm{HR}}$ and sulfate ${ }^{13}$. Driven by extreme temperatures ${ }^{49}$, silicate weathering is thought to have intensified during this time ${ }^{46,50}$, likely leading to increased release of $\mathrm{Fe}_{\mathrm{HR}}$ from parent silicate minerals ${ }^{28}$ and thus a disproportionate increase in the flux of $\mathrm{Fe}_{\mathrm{HR}}$ relative to sulfate. In addition, under the arid climate of the Permo-Triassic, dust production, and therefore the aeolian $\mathrm{Fe}$ flux, would also be higher ${ }^{51}$, which may have been further exacerbated at the PTB by the loss of terrestrial vegetation that led to soil destabilization ${ }^{52}$. On a global scale, these continental sources represent the greatest potential flux of $\mathrm{Fe}_{\mathrm{HR}}{ }^{13,28}$; however, on a more regional scale, hydrothermal inputs could also be important. There is indeed evidence that the Arabian Margin was in close proximity to a hydrothermal source of $\mathrm{Fe}(\mathrm{II})$, both from mid-Permian basalts underlying the deep basin sediments ${ }^{24}$ and from a spreading centre in the Neo-Tethys ${ }^{53}$. Temporally limited deep basin anoxia, identified here, provides a plausible mechanism for the transport of this $\mathrm{Fe}(\mathrm{II})$ during the Late Permian and occasionally in the Early Triassic. Regardless of the Fe source, anoxic conditions would still be required to explain the observed $\mathrm{Fe}_{\mathrm{HR}}$ enrichments across the shelf-to-basin transect. Thus there are numerous reasons why the $\mathrm{Fe}_{\mathrm{HR}}$-to-sulfate ratio of the oceans may have been skewed in favour of ferruginous conditions and we expect a combination of mechanisms to be important.

The presence of deep water anoxia on the Late Permian Arabian Margin (Fig. 3) suggests that the oceans were already primed for a later expansion of anoxic conditions and subsequent environmental crisis. This could represent the interplay of poor oxygenation due to sluggish circulation and high oxygen consumption during organic matter decay in a nutrient rich, highly productive Late Permian ocean ${ }^{54,55}$. Moving upwards to the EI itself, the mid-slope anoxic episode recorded here corresponds to the negative PTB carbon isotope excursion, a record that is dominated by a flux of isotopically light carbon to the atmosphere from a combination of methane, volcanism or a decrease in the removal of light carbon resulting from the terrestrial mass mortality ${ }^{56,57}$. This observation is consistent with numerous sections worldwide ${ }^{9,46,58,59}$, whereby slope and shallow water anoxia is thought to have been driven by nutrient loading from either a weathering pulse, increased soil erosion at the $\mathrm{PTB}^{9,46,58}$ (Fig. 5), or the upwelling of deep water anoxia/euxinia ${ }^{60}$.

During the protracted recovery period, our new data are consistent with previous suggestions for the episodic nature of anoxic events ${ }^{4,10,11}$. For the first time, however, we can also identify that the maximum extent of anoxia across the Arabian Margin is consistently associated with the globally recorded positive carbon isotope excursions (CIEs; Fig. 5) at both the Dienerian/Smithian boundary (shallow water anoxia) and the 
Smithian/Spathian boundary (mid-slope anoxia). Unfortunately, our records do not extend to the positive CIE of the Early/Middle Triassic boundary, but we would predict a further redevelopment of anoxia at this point. Although some published records show this relationship $11,43,61,62$, data for the Early Triassic provide mixed observations, often with no consistent pattern of anoxia ${ }^{4,11}$ or correlation with the negative $\mathrm{CIEs}^{10,59}$. The relationship between redox evolution and the $\delta^{13} \mathrm{C}$ record has implications for the driving mechanisms of anoxia and the role of internal feedback versus external forcing processes. Some of the differences in redox records will reflect palaeogeography and palaeodepth variations, where only a snapshot of the complex redox structure has been seen previously, in comparison with the vertical resolution afforded by the Arabian Margin sites. We also expect the lack of global consistency to be due to limitations in the redox proxies previously used, as they have been unable to identify anoxic ferruginous conditions.

The end-Dienerian event coincides with peak Early Triassic sedimentation $\operatorname{rates}^{47}$ (Fig. 5c), suggesting that high weathering rates and nutrient influxes could have driven the water column anoxic. In contrast, the Smithian/Spathian boundary event occurred during an apparent decrease in global weathering rates ${ }^{47}$. The event is, however, closely associated with decreasing temperatures after the Late Smithian equatorial thermal maximum $^{49}$ (Fig. 4). Greater ocean stagnation may be expected at the thermal maximum, and although the reconstructed temperature drop is relatively modest, it may have driven a reinvigoration of circulation that stimulated productivity or led to upwelling of anoxic waters.

The periodic development of anoxic ferruginous conditions on the Arabian Margin has major implications for the mass extinction event itself, and for biogeochemical cycling in general across this interval. Sulfide is highly toxic to almost all eukaryotes at micromolar concentrations ${ }^{2}$ and is therefore a kill mechanism in its own right, but the lack of euxinia suggests that sulfide was not responsible for the extinction in this area of the Neo-Tethys, a conclusion that has also recently been suggested for parts of the Palaeo-Tethys ${ }^{63}$. Organisms can adapt to low oxygen conditions (for example, the Lilliput effect ${ }^{64}$ ), and low oxygen tolerant species are selectively seen in the Early Triassic fossil record ${ }^{2,36}$. However, periods of regionally stable oxygenation appear to facilitate exceptional biotic recovery during the Griesbachian on the Arabian Margin. Thus, the rapid and repeated development of anoxic, but non sulfidic, conditions must have placed a major restriction on the biota in this area.

The precise chemical state of the water column also has major implications for the biogeochemical cycling of nutrients such as $\mathrm{P}$ and N. Current carbon cycle models for this time period require the inclusion of a positive-feedback mechanism ${ }^{56,65}$, whereby under anoxic conditions $P$ is recycled back into the water column, thereby stimulating further productivity to drive the total organic carbon depositional flux and maintain anoxia ${ }^{66}$. Indeed, the P-feedback mechanism appears to be an essential part of driving global positive CIEs during $\mathrm{OAEs}^{67}$. This, however, is less applicable under ferruginous conditions, whereby $\mathrm{P}$ is more likely to be sequestered in the sediment during uptake by $\mathrm{Fe}$-(oxyhydr)oxide minerals ${ }^{68}$. The development of euxinia is also closely tied to the $\mathrm{N}$ cycle, being dependent on the mode of nitrogen supply to the photic zone ${ }^{16}$. The behaviour of $\mathrm{P}$ and $\mathrm{N}$ under these different chemical states has great potential to influence global biogeochemical cycles ${ }^{14,16}$, the longevity of anoxic events ${ }^{15}$ and therefore the timing of biotic recovery after the end-Permian mass extinction. These factors suggest that further evaluation of the global extent of ferruginous conditions is required to fully understand biogeochemical controls on anoxia and life across the end-Permian mass extinction and recovery.

In summary, episodes of locally anoxic ferruginous conditions identified across the Arabian Margin appear to be manifested as increases in the spatial extent and temporal stability of anoxia, corresponding to changes in the global carbon cycle driven by global mechanisms. Biotic recovery in the Neo-Tethys was rapid during longer periods of oxygenation, confirming that the Early Triassic represents a period of repeated environmental perturbations on a global scale, which had a highly variable manifestation. The exact regional redox expression of anoxia, in terms of structure and chemical state, was likely dictated by local productivity, bathymetry and circulation differences between the Early Triassic oceans, as well as the local supply of $\mathrm{Fe}_{\mathrm{HR}}$ and regional sulfate drawdown ${ }^{13}$. The implications of the dominance of ferruginous conditions during this complex event require further investigation, but these data establish an important link between the precise chemical state of anoxic events and both carbon cycle stability and biotic resilience.

\section{Methods}

Fe-speciation and Fe/Al. Weathered surfaces were removed from rock samples using a diamond-tipped saw. Samples were then fragmented and powdered using a jaw crusher and Tema mill with Tungsten Carbide barrel. Fe-speciation extractions were performed according to the calibrated extraction procedure ${ }^{12}$, whereby $\mathrm{Fe}_{\mathrm{Carb}}$ was extracted with $\mathrm{Na}$-acetate at $\mathrm{pH} 4.5$ and $50^{\circ} \mathrm{C}$ for $48 \mathrm{~h}$,

$\mathrm{Fe}_{\mathrm{Ox}}$ was extracted via $\mathrm{Na}$-dithionite at $\mathrm{pH} 4.8$ for $2 \mathrm{~h}$, and $\mathrm{Fe}_{\mathrm{Mag}}$ was extracted with ammonium oxalate for $6 \mathrm{~h} . \mathrm{Fe}_{\mathrm{T}}$ extractions were performed on ashed samples ( $8 \mathrm{~h}$ at $550^{\circ} \mathrm{C}$ ) using $\mathrm{HNO}_{3}-\mathrm{HF}-\mathrm{HClO}_{4}$. Boric acid was used to prevent the formation of $\mathrm{Al}$ complexes, allowing $\mathrm{Fe} / \mathrm{Al}$ to be determined on the same extractions. All Fe concentrations were measured via atomic absorption spectrometry and replicate extractions gave a relative standard deviation (RSD) of $<5 \%$ for all steps. Pyrite Fe was determined stoichiometrically by weight from precipitated $\mathrm{Ag}_{2} \mathrm{~S}$ after chromous chloride distillation ${ }^{69}$. Fe/Al ratios were measured on the total extracts using optical emission spectrometry, with replicate extractions giving a RSD of $<1.7 \%$.

Pyrite sulfur isotopes. Pyrite S-isotope compositions $\left(\delta^{34} S_{\text {pyrite }}\right)$ are also used to give further insight into sulfur cycling and to provide additional support for water column redox interpretations. $\delta^{34} S_{\text {pyrite }}$ analyses were performed on the $\mathrm{Ag}_{2} \mathrm{~S}$ precipitate produced from the chromous chloride distillation, using an Elementar Pyrocube coupled to an Isoprime stable isotope mass spectrometer.

Carbon isotopes. All measurements were carried out on a Thermo Finnigan GASBENCH II linked online to a Thermo Finnigan DELTA V 94 isotope ratio mass spectrometer at the Museum fuer Naturkunde Berlin, Germany. Isotope ratios are reported in $\delta$-notation in (\%) relative to the Vienna Peedee Belemnite. The analytical reproducibility of $\delta^{13} \mathrm{C}_{\mathrm{carb}}$ and $\delta^{18} \mathrm{O}$ values is each generally better than $\pm 0.2 \%$ ( 2 s.d.)

Data availability. All data are provided in the Supplementary Information.

\section{References}

1. Jenkyns, H. C. Geochemistry of oceanic anoxic events. Geochem. Geophys. Geosyst. 11, Q03004 (2010).

2. Knoll, A. H., Barnbach, R. K., Payne, J. L., Pruss, S. \& Fischer, W. W. Paleophysiology and end-Permian mass extinction. Earth Planet. Sci. Lett. 256, 295-313 (2007).

3. Kump, L. R., Pavlov, A. \& Arthur, M. A. Massive release of hydrogen sulfide to the surface ocean and atmosphere during intervals of oceanic anoxia. Geology 33, 397-400 (2005).

4. Wignall, P. B. et al. An 80 million year oceanic redox history from Permian to Jurassic pelagic sediments of the Mino-Tamba terrane, SW Japan, and the origin of four mass extinctions. Global Planet. Change 71, 109-123 (2010).

5. Wignall, P. B. \& Twitchett, R. J. Oceanic anoxia and the end Permian mass extinction. Science 272, 1155-1158 (1996).

6. Grice, K. et al. Photic zone euxinia during the Permian-Triassic superanoxic event. Science 307, 706-709 (2005).

7. Erwin, D. H. The Permo-Triassic Extinction. Nature 367, 231-236 (1994).

8. Isozaki, Y. Permo-triassic boundary superanoxia and stratified superocean: records from lost deep sea. Science 276, 235-238 (1997).

9. Algeo, T. J. et al. Changes in productivity and redox conditions in the Panthalassic Ocean during the latest Permian. Geology 38, 187-190 (2010). 
10. Feng, Q. \& Algeo, T. Evolution of oceanic redox conditions during the Permo-Triassic: evidence from radiolarian deepwater facies. Earth Sci. Rev. 137, 34-51 (2014).

11. Grasby, S. E., Beauchamp, B., Embry, A. \& Sanei, H. Recurrent Early Triassic ocean anoxia. Geology 41, 175-178 (2013).

12. Poulton, S. W. \& Canfield, D. E. Development of a sequential extraction procedure for iron: implications for iron partitioning in continentally derived particulates. Chem. Geol. 214, 209-221 (2005).

13. Poulton, S. W. \& Canfield, D. E. Ferruginous conditions: a dominant feature of the ocean through earth's history. Elements 7, 107-112 (2011).

14. März, C. et al. Redox sensitivity of $\mathrm{P}$ cycling during marine black shale formation: dynamics of sulfidic and anoxic, non-sulfidic bottom waters. Geochim. Cosmochim. Acta 72, 3703-3717 (2008).

15. Poulton, S. W. et al. A continental-weathering control on orbitally driven redox-nutrient cycling during Cretaceous Oceanic Anoxic Event 2. Geology 43, 963-966 (2015)

16. Boyle, R. A. et al. Nitrogen cycle feedbacks as a control on euxinia in the midProterozoic ocean. Nat. Commun. 4, 1533 (2013).

17. Kendall, B. et al. Pervasive oxygenation along late Archaean ocean margins. Nature Geoscience 3, 647-652 (2010).

18. Poulton, S. W., Fralick, P. W. \& Canfield, D. E. Spatial variability in oceanic redox structure 1.8 billion years ago. Nat. Geosci. 3, 486-490 (2010).

19. Insalaco, E. et al. Upper Dalan Member and Kangan Formation between the Zagros Mountains and offshore Fars, Iran: depositional system, biostratigraphy and stratigraphic architecture. GeoArabia 11, 75-176 (2006).

20. Richoz, S. et al.in Permo-Triassic Sequence of the Arabian Plate (ed. M. Pöpperlreiter) (EAGE Special Volume, 2014).

21. Clarkson, M. O. et al. A new high-resolution delta C-13 record for the Early Triassic: insights from the Arabian platform. Gondwana Res. 24, 233-242 (2013).

22. Watts, K. F. Triassic carbonate submarine fans along the Arabian platform margin, Sumeini group, Oman. Sedimentology 35, 43-71 (1988).

23. Richoz, S. et al.in IGCP 572, 2nd field workshop (eds A. aud \& M. Bernecker) 79-100 (GUtech, 2010).

24. Baud, A. et al. The Buday'ah Formation, Sultanate of Oman: a Middle Permian to Early Triassic oceanic record of the Neotethys and the late Induan microsphere bloom. J. Asian Earth Sci. 43, 130-144 (2012).

25. Woods, A. D. \& Baud, A. Anachronistic facies from a drowned Lower Triassic carbonate platform: lower member of the Alwa Formation (Ba'id Exotic), Oman Mountains. Sediment. Geol. 209, 1-14 (2008).

26. Pillevuit, A., Marcoux, J., Stampfli, G. \& Baud, A. The Oman exotics: a key to the understanding of the Neotethyan geodynamic evolution. Geodin. Acta 10, 209-238 (1997).

27. Richoz, S. Stratigraphie et variations isotopiques du carbone dans le Permien supérieur et le Trias inférieur de quelques localitiés de la Néothéthys (Turquie, Oman et Iran). Mem. Geol. (Lausanne) 46, 275 (2006).

28. Poulton, S. W. \& Raiswell, R. The low-temperature geochemical cycle of iron: from continental fluxes to marine sediment deposition. Am. J. Sci. 302, 774-805 (2002).

29. Canfield, D. E., Lyons, T. W. \& Raiswell, R. A model for iron deposition to euxinic Black Sea sediments. Am. J. Sci. 296, 818-834 (1996).

30. Poulton, S. W., Fralick, P. W. \& Canfield, D. E. The transition to a sulphidic ocean similar to 1.84 billion years ago. Nature 431, 173-177 (2004).

31. Raiswell, R. \& Canfield, D. E. Sources of iron for pyrite formation in marine sediments. Am. J. Sci. 298, 219-245 (1998).

32. Raiswell, R., Newton, R. \& Wignall, P. B. An indicator of water-column anoxia: resolution of biofacies variations in the Kimmeridge Clay (Upper Jurassic, UK). J. Sediment. Res. 71, 286-294 (2001).

33. Lyons, T. W. \& Severmann, S. A critical look at iron paleoredox proxies: new insights from modern euxinic marine basins. Geochim. Cosmochim. Acta 70, 5698-5722 (2006).

34. Raiswell, R. et al. Turbidite depositional influences on the diagenesis of Beecher's Trilobite Bed and the Hunsruck Slate; Sites of soft tissue pyritization. Am. J. Sci. 308, 105-129 (2008).

35. Clarkson, M. O., Poulton, S. W., Guilbaud, R. \& Wood, R. Assessing the utility of $\mathrm{Fe} / \mathrm{Al}$ and $\mathrm{Fe}$-speciation to record water column redox conditions in carbonate-rich sediments. Chem. Geol. 382, 111-122 (2014).

36. Twitchett, R. J., Krystyn, L., Baud, A., Wheeley, J. R. \& Richoz, S. Rapid marine recovery after the end-Permian mass-extinction event in the absence of marine anoxia. Geology 32, 805-808 (2004).

37. Woods, A. D. Assessing Early Triassic Paleoceanographic conditions vias unusual sedimentary fabrics and features. Earth Sci. Rev. 137, 6-18 (2013).

38. Shen, Y. N., Canfield, D. E. \& Knoll, A. H. Middle proterozoic ocean chemistry: evidence from the McArthur Basin, northern Australia. Am. J. Sci. 302, 81-109 (2002).

39. Canfield, D. E. Isotope fractionation by natural populations of sulfate-reducing bacteria. Geochim. Cosmochim. Acta 65, 1117-1124 (2001).

40. Newton, R. J., Pevitt, E. L., Wignall, P. B. \& Bottrell, S. H. Large shifts in the isotopic composition of seawater sulphate across the Permo-Triassic boundary in northern Italy. Earth Planet. Sci. Lett. 218, 331-345 (2004).
41. Song, H. et al. Early Triassic seawater sulfate drawdown. Geochim. Cosmochim. Acta 128, 95-113 (2014).

42. Habicht, K. S., Gade, M., Thamdrup, B., Berg, P. \& Canfield, D. E. Calibration of sulfate levels in the Archean Ocean. Science 298, 2372-2374 (2002).

43. Sun, Y. D. et al. High amplitude redox changes in the late Early Triassic of South China and the Smithian-Spathian extinction. Palaeogeogr.

Palaeoclimatol. Palaeoecol. 427, 62-78 (2015).

44. Scholz, F., Severmann, S., McManus, J. \& Hensen, C. Beyond the Black Sea paradigm: the sedimentary fingerprint of an open-marine iron shuttle. Geochim. Cosmochim. Acta 127, 368-380 (2014).

45. Luo, G. et al. Isotopic evidence for an anomalously low oceanic sulfate concentration following end-Permian mass extinction. Earth Planet. Sci. Lett. 300, 101-111 (2010).

46. Algeo, T. J., Chen, Z. Q., Fraiser, M. L. \& Twitchett, R. J. Terrestrial-marine teleconnections in the collapse and rebuilding of Early Triassic marine ecosystems. Palaeogeogr. Palaeoclimatol. Palaeoecol. 308, 1-11 (2011).

47. Algeo, T. J. \& Twitchett, R. J. Anomalous Early Triassic sediment fluxes due to elevated weathering rates and their biological consequences. Geology 38, 1023-1026 (2010).

48. Warren, J. K. Evaporites through time: tectonic, climatic and eustatic controls in marine and nonmarine deposits. Earth Sci. Rev. 98, 217-268 (2010).

49. Sun, Y. D. et al. Lethally hot temperatures during the Early Triassic Greenhouse. Science 338, 366-370 (2012).

50. Algeo, T. J. et al. Spatial variation in sediment fluxes, redox conditions, and productivity in the Permian-Triassic Panthalassic Ocean. Palaeogeogr. Palaeoclimatol. Palaeoecol. 308, 65-83 (2011).

51. Jickells, T. et al. Global iron connections between desert dust, ocean biogeochemistry, and climate. Science 308, 67-71 (2005).

52. Sephton, M. A. et al. Catastrophic soil erosion during the end-Permian biotic crisis. Geology 33, 941-944 (2005).

53. Stampfli, G. M. \& Borel, G. D. A plate tectonic model for the Paleozoic and Mesozoic constrained by dynamic plate boundaries and restored synthetic oceanic isochrons. Earth Planet. Sci. Lett. 196, 17-33 (2002).

54. Winguth, A. M. E. \& Maier-Reimer, E. Causes of the marine productivity and oxygen changes associated with the Permian-Triassic boundary: a re-evaluation with ocean general circulation models. Mar. Geol. 217, 283-304 (2005).

55. Schobben, M. et al. Flourishing ocean drives the end-Permian marine mass extinction. Proc. Natl Acad. Sci. USA 112, 10298-10303 (2015).

56. Berner, R. A. Examination of hypotheses for the Permo-Triassic boundary extinction by carbon cycle modeling. Proc. Natl Acad. Sci. USA 99, 4172-4177 (2002).

57. Clarkson, M. O. et al. Ocean acidification and the Permo-Triassic mass extinction. Science 348, 229-232 (2015).

58. Algeo, T. J. et al. Plankton and productivity during the Permian-Triassic boundary crisis: an analysis of organic carbon fluxes. Global Planet. Change 105, 52-67 (2013).

59. Grasby, S. E. \& Beauchamp, B. Latest Permian to Early Triassic basin-to-shelf anoxia in the Sverdrup Basin, Arctic Canada. Chem. Geol. 264, 232-246 (2009).

60. Algeo, T. J. et al. The Permian - Triassic boundary at Nhi Tao, Vietnam: evidence for recurrent influx of sulfidic watermasses to a shallow-marine carbonate platform. Palaeogeogr. Palaeoclimatol. Palaeoecol. 252, 304-327 (2007).

61. Galfetti, T. et al. Timing of the Early Triassic carbon cycle perturbations inferred from new U-Pb ages and ammonoid biochronozones. Earth Planet. Sci. Lett. 258, 593-604 (2007).

62. Galfetti, T. et al. Late Early Triassic climate change: insights from carbonate carbon isotopes, sedimentary evolution and ammonoid paleobiogeography. Palaeogeogr. Palaeoclimatol. Palaeoecol. 243, 394-411 (2007).

63. Xiang, L. et al. Oceanic redox evolution across the end-Permian mass extinction at Shangsi, South China. Palaeogeogr. Palaeoclimatol. Palaeoecol. 448, 59-71 (2015).

64. Twitchett, R. J. The Lilliput effect in the aftermath of the end-Permian extinction event. Palaeogeogr. Palaeoclimatol. Palaeoecol. 252, 132-144 (2007).

65. Payne, J. L. \& Kump, L. R. Evidence for recurrent Early Triassic massive volcanism from quantitative interpretation of carbon isotope fluctuations. Earth Planet. Sci. Lett. 256, 264-277 (2007).

66. Van Cappellen, P. \& Ingall, E. D. Benthic phosphorus regeneration, net primary production, and ocean anoxia - a model of the coupled marine biogeochemical cycles of carbon and phosphorus. Paleoceanography 9, 677-692 (1994).

67. Bachan, A. \& Payne, J. Modelling the impact of pulsed CAMP volcanism on pCO 2 and $\delta 13 \mathrm{C}$ across the Triassic-Jurassic transition. Geological Mag. 153, 252-270 (2016).

68. März, C. et al. Redox sensitivity of $\mathrm{P}$ cycling during marine black shale formation: dynamics of sulfidic and anoxic, non-sulfidic bottom waters. Geochim. Cosmochim. Acta 72, 3703-3717 (2008).

69. Canfield, D. E., Raiswell, R., Westrich, J. T., Reaves, C. M. \& Berner, R. A. The use of chromium reduction in the analysis of reduced inorganic sulfur in sediments and shales. Chem. Geol. 54, 149-155 (1986). 
70. Richoz, S. et al. Permian-Triassic boundary interval in the Middle East (Iran and N. Oman): progressive environmental change from detailed carbonate carbon isotope marine curve and sedimentary evolution. J. Asian Earth Sci. 39, 236-253 (2010).

\section{Acknowledgements}

M.O.C. acknowledges funding from the Edinburgh University Principal's Career Development Scholarship, International Centre for Carbonate Reservoirs and the Moray Endowment Award. R.A.W. and S.W.P. acknowledge support from the Natural Environment Research Council (NERC) through the 'Co-evolution of Life and the Planet' scheme. This is a contribution to the International Geoscience Programme (IGCP) 572 with S.R. sponsored for fieldwork by the Austrian National Committee (Austrian Academy of Sciences) 572. We thank Romain Guilbaud, Walter Geibert and Alex Thomas for laboratory assistance, Paul Wignall for comments on an early manuscript, and four anonymous reviewers who helped make significant improvements to the paper.

\section{Author contributions}

M.O.C. undertook field and laboratory work, and led manuscript writing with significant contributions from S.W.P., R.A.W., S.R. and R.J.N. S.R. guided and supported field sampling, R.J.N. undertook sulfur isotope analyses, S.W.P. provided technical facilities and expertise, S.K. provided carbon isotope measurements, F.B. undertook Fe/Al measurements and L.K. undertook conodont analysis and provided field support.

\section{Additional information}

Supplementary Information accompanies this paper at http://www.nature.com/ naturecommunications

Competing financial interests: The authors declare no competing financial interests.

Reprints and permission information is available online at http://npg.nature.com/ reprintsandpermissions/

How to cite this article: Clarkson, M. O. et al. Dynamic anoxic ferruginous conditions during the end-Permian mass extinction and recovery. Nat. Commun. 7:12236 doi: 10.1038/ncomms12236 (2016).

\section{(c) (i)}

This work is licensed under a Creative Commons Attribution 4.0 International License. The images or other third party material in this article are included in the article's Creative Commons license, unless indicated otherwise in the credit line; if the material is not included under the Creative Commons license, users will need to obtain permission from the license holder to reproduce the material. To view a copy of this license, visit http://creativecommons.org/licenses/by/4.0/

(C) The Author(s) 2016 